\title{
TRANSFORMATIONAL LEADERSHIP IN THE SERVICE OF ORGANIZATIONAL CHANGES
}

\author{
Ivica MATEJIĆ ${ }^{1}$, Mihailo ĆURČIĆ ${ }^{2^{*}}$, Radan KOSTIĆ ${ }^{3}$ \\ ${ }^{1}$ Faculty of Economics, University of Kragujevac, Liceja Kneževine Srbije 3, Kragujevac, Serbia, \\ ivica_matejic@yahoo.com \\ ${ }^{2}$ Military Academy, University of Defense, Pavla Jurišića Šturma 33, Belgrade, Serbia, \\ curcicmihailo@gmail.com \\ ${ }^{3}$ Military Academy, University of Defense, Pavla Jurišića Šturma 33, Belgrade, Serbia, \\ radankole@gmail.com
}

\begin{abstract}
The complex and dynamic environment in which modern companies operate requires frequent organizational changes that are used as a mechanism for adapting the company's business to market requirements, in order to improve or maintain a competitive advantage. Mergers and acquisitions, as a complex form of organizational change of companies, represent a relevant problem area of research. Since the success of organizational change depends on two important factors, leaders and employees, the aim of this research is to identify the interdependence of transformational leadership, job satisfaction and commitment to organizational change by employees in the post-acquisition period. The research results show that there is interdependence between transformational leadership, job satisfaction and commitment to organizational change in the post-acquisition period. The empirical research was conducted in 2021, using a survey method. Data were analyzed using Pearson's correlation and single as well as multiple regression method. A sample of 129 respondents was taken into accounts, who are employed in companies in the Republic of Serbia that have gone through the acquisition process in the last five years.
\end{abstract}

Keywords: transformational leadership, organizational change, post-acquisition process

Original scientific paper

Received: 25.10.2021

Accepted: 10.11.2021

Available online: 10.11 .2021

\section{Introduction}

A leader is a key factor in the success of any organization, and this is especially evident in the process of organizational changes. Every business in an organization is characterized by a dynamic environment that requires a dynamic leader. In a specific environment in which modern companies operate, the leadership process is crucial in transformational changes in the organization. The leadership process and the process of transformational changes have a causeand-effect relationship. A true leader recognizes the need for change in the organization, initiates organizational change and is the most important factor in the process of organizational changes. Also, organizational changes give birth to leaders who, with their qualities, abilities and authority, impose themselves as a beacon that directs the entire process of organizational

\footnotetext{
${ }^{*}$ Corresponding author
} 
change. It was the process of organizational change that initiated the emergence and development of the concept of transactional and transformational leadership. Some authors defined transformational leadership as process of achieving collective goals through increasing the motivation of leaders and followers, in order to achieve intended changes (Pierce \& Newstrom, 2000).

Acquisition involves a process that requires complex and detailed planning of a company's activities in order to successfully execute organizational changes. However, even the most detailed plan does not ensure the success of the acquisition process. Effective leadership and management ability are a key variable in the success of acquisitions (Nemanich \& Keller, 2007). Many authors believe that the most important phase for the success of the acquisition process is the integration phase, since through implementation the value of the acquisition process is created (Haspeslagh \& Jemison, 1987). It is at this stage that the leader has a decisive influence, as it serves as a link between the strategic acquisition plans and the employees. He is responsible for the employees to implement strategic plans, ideas and goals in accordance with the ideas of the acquisition, in order to create value. In many cases, the resistance of employees to changes hinders the ability of the acquiring company to create the planned value and achieve the necessary degree of integration (Babić \& Savović, 2009). A leader, through a transformational leadership style, is responsible for mitigating or completely eradicating employee resistance, and creating the conditions for creating company value that stems from the acquisition process.

The subject of research in this paper is the transformational leadership style, as a leadership style characteristic of organizational change in companies, and job satisfaction and commitment to organizational change as determinants of successful implementation of acquisition strategies and plans. The aim of the research is to identify the interdependence of transformational leadership, job satisfaction and commitment to organizational change in the post-acquisition period. Two sub-goals have emerged from this goal, namely the identification of the interdependence of transformational leadership and job satisfaction and the identification of the interdependence of transformational leadership and commitment to organizational change.

\section{Research Methodology}

Acquisitions, as one of the common forms of organizational change, can lead to reduced employee satisfaction, resulting in resistance to organizational change and less desire to stay in the new company (Rafferty \& Restubog, 2010). The ability of leaders during organizational change is reflected in the reduction of employee dissatisfaction and the integration of employees into the planning process of organizational change (Kiessling \& Harvey, 2006). A leader is a link between strategy, goals, acquisition plans and employees. Transformational leadership, as the most common form of leadership during organizational change, can reduce uncertainty and develop a positive attitude related to organizational change, and thus build employee connections with organizational change (Farahnak et al., 2020; Savović, 2017).

The intensification of organizational change, which has caused a dynamic business environment, has initiated a large number of studies of transformational leadership (Yukl, 1999; Antonakis et al., 2003; Judge \& Piccolo, 2004; Wang et al., 2017). Numerous studies have shown that transformational leadership has a positive impact on organizational commitment and job satisfaction (Long et al., 2014; Nielsen et al., 2009). The interdependence between transformational leadership and acceptance of change, adaptation to change and satisfaction with change by employees was confirmed (Nemanich \& Keller, 2007; Wang et al., 2017), and 
that transformational leadership has a significant impact on employee commitment to organizational change (Herold et al., 2008; Rafferty \& Griffin, 2004; Top et al., 2015).

Based on the conclusions from the previous researches and analysis of key factors of transformational leadership, job satisfaction and commitment to organizational changes, the research idea in this paper refers to determining the interdependence of transformational leadership and job satisfaction and commitment to organizational change by employees. In accordance with the stated research idea and the proposed research model, research hypotheses are defined. The basic hypothesis of the research is that there is a statistically significant interdependence of transformational leadership, job satisfaction and commitment to organizational change. Based on the basic hypothesis, three derived hypotheses were formed as follows:

H1: There is a statistically significant interdependence of transformational leadership and job satisfaction;

H2: There is a statistically significant interdependence of transformational leadership and commitment to organizational change;

H3: There is a statistically significant interdependence of job satisfaction and commitment to organizational change.

\section{Data Formulation}

Empirical research was conducted in 2021 in companies in the Republic of Serbia that went through the acquisition process, on the basis of 129 respondents, using the survey method. A questionnaire containing 31 statements that are evaluated on the Likert scale with values from 1 to 5 was used to collect research data. The first 16 statements refer to the factors of transformational leadership (Savović, 2017). The statements are grouped into four factors of transformational leadership (Avolio et al., 1999; Savović, 2017). The next seven statements refer to commitment to organizational change, while the last eight statements refer to job satisfaction (Parvin\&Kabir, 2011). The structure of the respondents is shown in following figures: $1-6$.

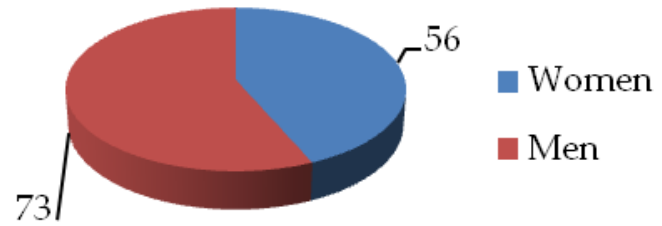

Figure 1. Gender Structure Source: Authors' Survey

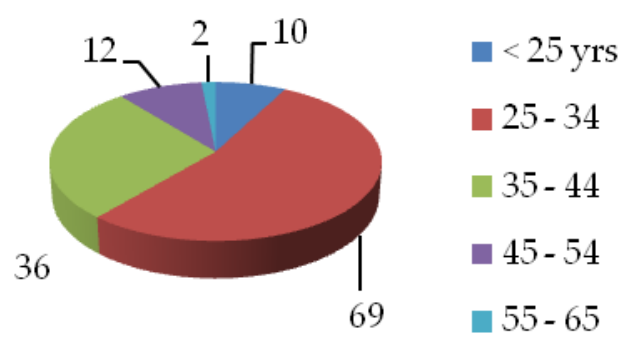

Figure 2. Age Structure Source: Authors' Survey 


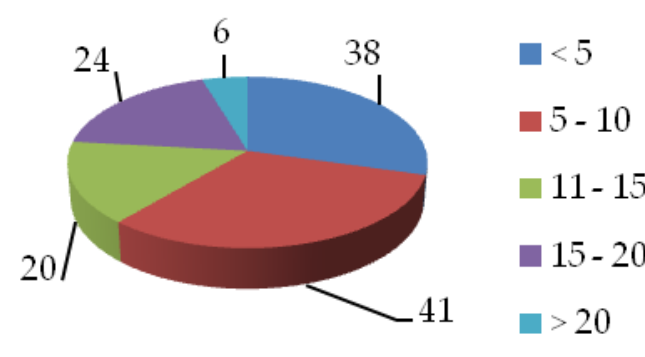

Figure 3. Work Experience Structure Source: Authors' Survey

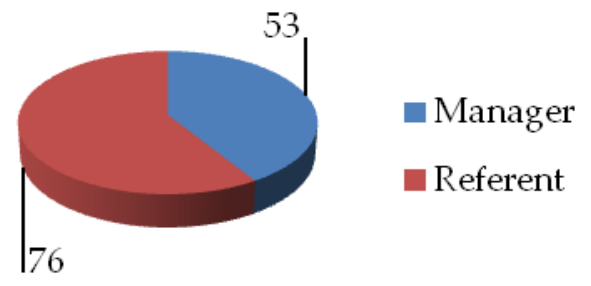

Figure 5. Position Structure Source: Authors' Survey

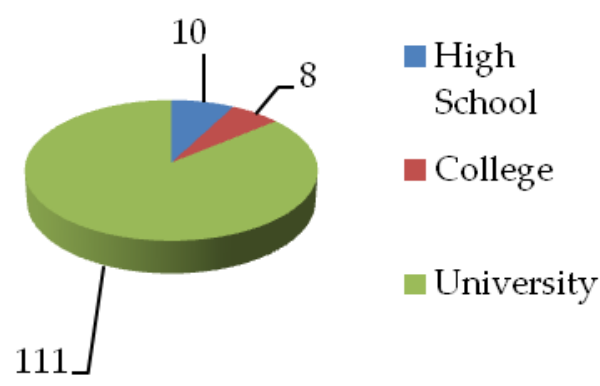

Figure 4. Level of Education Source: Authors' Survey

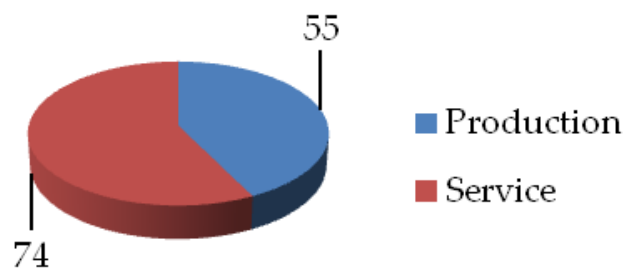

Figure 6. Type of Activity Source: Authors' Survey

\section{Results and Discussion}

At the very beginning of the data analysis, an analysis of the reliability of the data obtained by the questionnaire was performed, and Chronbach's Alpha value of 0.952 was obtained. The conclusion is that the data obtained by the questionnaire are reliable. Table 1 shows the Cronbach alpha values for all individual variables. For all variables, these values are higher than the threshold of 0.7 , which indicates their reliability, i.e. the internal consistency of the statements through which these factors are measured:

Table 1. Cronbach's Alpha Values

\begin{tabular}{cc}
\hline Variables & Cronbach's Alpha \\
\hline Transformational Leadership & 0.933 \\
Job Satisfaction & 0.944 \\
Commitment to Changes & 0.954 \\
\hline
\end{tabular}

Source: Authors' Survey

In order to examine the interdependence of transformational leadership, job satisfaction and commitment to organizational change, a correlation analysis was performed, and the values of the Pearson coefficient were observed (Table 2). 
Table 2. Pearson's Correlation Coefficient

\begin{tabular}{|c|c|c|c|c|}
\hline \multicolumn{2}{|c|}{ Variables } & \multirow{2}{*}{$\begin{array}{l}\text { Transformational } \\
\text { Leadership }\end{array}$} & \multirow[t]{2}{*}{ Job Satisfaction } & \multirow[t]{2}{*}{$\begin{array}{c}\text { Commitment } \\
\text { to Changes }\end{array}$} \\
\hline \multirow{3}{*}{$\begin{array}{c}\text { Transformational } \\
\text { Leadership }\end{array}$} & Pearson & & & \\
\hline & Correlation & & & \\
\hline & $\begin{array}{l}\text { Significance } \\
\mathrm{N}\end{array}$ & 129 & & \\
\hline \multirow{3}{*}{ Job Satisfaction } & $\begin{array}{l}\text { Pearson } \\
\text { Correlation }\end{array}$ & $0.823^{* *}$ & 1 & \\
\hline & Significance & 0.000 & & \\
\hline & $\mathrm{N}$ & 129 & 129 & \\
\hline \multirow{3}{*}{$\begin{array}{c}\text { Commitment to } \\
\text { Changes }\end{array}$} & $\begin{array}{l}\text { Pearson } \\
\text { Correlation }\end{array}$ & $0.684^{* *}$ & $0.721^{* *}$ & 1 \\
\hline & Significance & 0.000 & 0.000 & \\
\hline & $\mathrm{N}$ & 129 & 129 & 129 \\
\hline
\end{tabular}

**. Correlation is significant at the 0.01 level (2-tailed).

*. Correlation is significant at the 0.05 level (2-tailed).

As can be seen from Table 2, the value of the Pearson coefficient between the variables is statistically significant at the level of $0.01(\mathrm{p}<0.01)$. There is a positive linear correlation between transformational leadership, job satisfaction, and commitment to organizational change. The highest degree of linear correlation (high correlation) exists between transformational leadership and job satisfaction $\left(\mathrm{r}=0.823^{* *}\right)$, while this degree is the lowest (moderately high correlation) between transformational leadership and commitment to organizational change $(\mathrm{r}=$ $\left.0.684^{* *}\right)$.In order to determine the nature of the connection between transformational leadership and job satisfaction, i.e. form of dependence between the observed phenomena, regression analysis was performed. Job satisfaction is defined as a dependent variable (Table 3).

Table 3. Simple Regression Values

\begin{tabular}{ccccccc}
\hline $\begin{array}{c}\text { Independent } \\
\text { Variable }\end{array}$ & $\boldsymbol{\beta}$ & $\mathbf{t}$ & $\mathbf{R}^{2}$ & $\begin{array}{c}\text { Adjusted } \\
\mathbf{R}^{2}\end{array}$ & $\begin{array}{c}\text { Std. Error } \\
\text { of } \\
\text { Estimate }\end{array}$ & sig. \\
\hline $\begin{array}{c}\text { Transformational } \\
\text { Leadership }\end{array}$ & 0.823 & 16.328 & 0.677 & 0.675 & 0.63753 & 0.000 \\
\hline
\end{tabular}

Source: Authors' Survey

As can be seen from the results shown in Table 3, the coefficient of determination obtained by simple regression analysis is $\mathrm{R}^{2}=0.677$, which shows that $67.7 \%$ of the variability of the dependent variable is described by the regression model of variability, i.e. under the influence of transformational leadership. The obtained value of the coefficient of determination is statistically significant $($ sig. $=0.000)$. To determine the nature of the relationship between transformational leadership and commitment to organizational change, a regression analysis was performed. Commitment to organizational change is defined as a dependent variable (Table 4).

Table 4. Simple Regression Values

\begin{tabular}{ccccccc}
\hline $\begin{array}{c}\text { Independent } \\
\text { Variable }\end{array}$ & $\boldsymbol{\beta}$ & $\mathbf{t}$ & $\mathbf{R}^{\mathbf{2}}$ & $\begin{array}{c}\text { Adjusted } \\
\mathbf{R}^{2}\end{array}$ & $\begin{array}{c}\text { Std. Error } \\
\text { of } \\
\text { Estimate }\end{array}$ & sig. \\
\hline $\begin{array}{c}\text { Transformational } \\
\text { Leadership }\end{array}$ & 0.684 & 10.576 & 0.468 & 0.464 & 0.60006 & 0.000 \\
\hline
\end{tabular}

Source: Authors' Survey 
As can be seen from the results shown in Table 4, the coefficient of determination obtained by multiple regression is $\mathrm{R}^{2}=0.468$, which shows that $46.8 \%$ of the variability of the dependent variable is described by the regression model of variability, i.e. under the influence of transformational leadership. The obtained value of the coefficient of determination is statistically significant $(\mathrm{sig} .=0.000)$. To determine the nature of the relationship between job satisfaction and commitment to organizational change, a regression analysis was performed. Commitment to organizational change is defined as a dependent variable (Table 5).

Table 5. Simple Regression Values

\begin{tabular}{ccccccc}
\hline $\begin{array}{c}\text { Independent } \\
\text { Variable }\end{array}$ & $\boldsymbol{\beta}$ & $\mathbf{t}$ & $\mathbf{R}^{2}$ & $\begin{array}{c}\text { Adjusted } \\
\mathbf{R}^{2}\end{array}$ & $\begin{array}{c}\text { Std. Error } \\
\text { of } \\
\text { Estimate }\end{array}$ & sig. \\
\hline $\begin{array}{c}\text { Job } \\
\text { Satisfaction }\end{array}$ & 0.721 & 11.737 & 0.520 & 0.517 & 0.56994 & 0.000 \\
\hline \multicolumn{7}{c}{ Source: Authors' Survey }
\end{tabular}

Source: Authors' Survey

As can be seen from the results shown in Table 5, the coefficient of determination obtained by multiple regression is $\mathrm{R}^{2}=0.520$, which shows that $52 \%$ of the variability of the dependent variable is described by the regression model of variability, i.e. it is influenced by job satisfaction. The obtained value of the coefficient of determination is statistically significant (sig. $=0.000)$. As a step forward in relation to previous research, and in order to examine the mediator role of job satisfaction in relation to the commitment to organizational change, a multiple regression analysis was performed. Transformational leadership was identified as a dependent variable, while job satisfaction and commitment to organizational change were defined as independent variables (Table 6).

Table 6. Multiple Regression Values

\begin{tabular}{|c|c|c|c|c|c|c|c|}
\hline $\begin{array}{c}\text { Independent } \\
\text { Variable }\end{array}$ & $\beta$ & $\mathbf{t}$ & $\mathbf{R}^{2}$ & $\begin{array}{c}\text { Adjusted } \\
\mathbf{R}^{2}\end{array}$ & $\begin{array}{c}\text { Std. Error } \\
\text { of } \\
\text { Estimate }\end{array}$ & sig. & VIF \\
\hline $\begin{array}{c}\text { Job } \\
\text { Satisfaction }\end{array}$ & 0.687 & 9.658 & 0.694 & 0.690 & 0.51532 & 0.000 & 2.085 \\
\hline $\begin{array}{l}\text { Commitment } \\
\text { to Changes }\end{array}$ & 0.189 & 2.658 & & & & 0.009 & 2.085 \\
\hline
\end{tabular}

If we compare the results shown in Table 6 with the results shown in Table 5, we conclude that job satisfaction has a mediating role in relation to commitment to organizational change ( $\beta$ coefficient decreased from 0.684 to 0.189 ). Given that the variance growth factor (VIF) is lower than five for both variables (VIF $=2.085$ ), we conclude that multiple regression analysis was justified.

The presented results of the conducted research confirmed the set hypotheses, as well as the results of previous research in which it was proven that transformational leadership has a positive impact on organizational commitment and job satisfaction (Long et al., 2014; Nielsen et al., 2009), acceptance of change, adaptation to change and satisfaction with change by employees (Nemanich \& Keller, 2007; Wang et al., 2017), and that transformational leadership has a significant impact on employee commitment to organizational change (Herold et al. , 2008; Rafferty \& Griffin, 2004; Top et al., 2015). Compared to previous research, a step forward has been made by examining the mediator impact of job satisfaction in relation to commitment to 
organizational change (Dung et al., 2020). The results of the research prove that job satisfaction has a mediating effect in relation to the commitment to organizational change.

The acquisition process is an extremely complex, uncertain and, above all, stressful period, both for the company being acquired, viewed as an entity, and for the company's employees. One third of all unsuccessful acquisitions are the result of resistance to change by employees, and when planning the acquisition process, special attention should be paid to this variable. As important as it is to define the acquisition process plan in detail and comprehensively, it is just as important to make a detailed implementation process plan. Without a successful implementation, it is impossible to create the value of a new company, and thus the acquisition process is considered unsuccessful. A key role in this process is played by the leader, who with his leadership style should provide employees with confidence in the well-being and success of organizational change. The leader should identify potential causes of employee resistance, and by adapting the leadership style to the needs of employees, bring the acquisition process closer to successful implementation.

This research confirmed previous research in which it was proven that transformational leadership style has a positive impact on job satisfaction as well as on the acceptance of organizational change. Through intellectual stimulation, the leader involves employees in organizational change, through raising their self-confidence and faith in their own abilities. With idealized influence and inspirational motivation, the leader sets him up as a leader who is a beacon that shows the way out of turbulent organizational changes. By his own attitude and behavior, he instills in the employees self-confidence in the success of organizational changes and thus reduces their resistance. Finally, through individual consideration, the leader identifies employees who have a negative or indecisive attitude toward organizational change and by paying attention to such employees' influences reducing the negative or building their positive attitude toward change. Employees who see a stable, capable and self-confident leader in front of them will more easily accept any changes than employees whose leader gives the impression of unreliability and insecurity.

\section{Conclusion}

A dynamic market environment requires companies to adapt and change their business. One of the ways to adapt to market changes is through acquisition processes. Acquisitions are an extremely complex and uncertain process. A detailed analysis of both one's own company and the company being acquired is important for the success of the acquisition process. During that analysis, both material and human resources are considered, but insufficient attention is paid to the human resources of the company being taken over. The company that is being taken over analyzes employees with "critical knowledge", while less attention is paid to the organizational culture of employees, job satisfaction and potential resistance of employees to organizational changes. Research has shown that the attitude of employees towards organizational change is one of the decisive factors on which the success of the implementation process depends, and thus the acquisition process itself.

The scientific contribution of this research can be viewed from two aspects. The first aspect is to confirm the results of previous research which show that there is interdependence between the factors of transformational leadership, job satisfaction and commitment to organizational change. Another aspect is reflected in the fact that this research was conducted in companies that have gone through the acquisition process in the last five years. The social contribution is reflected in the possibility of applying the results of this research in companies that are facing organizational changes. 
The limitation of this research is reflected in the small number of respondents in relation to the number of employees in companies that have undergone the acquisition process in the last five years (especially in the banking sector). It is necessary to increase the sample of respondents in future research in order to evaluate the results of this research. The only limitation is the use of the survey as a method of data collection. In the use of the survey, the problem of potentially giving "socially desirable answers" by the respondents was identified. The survey is based on the subjective perception of the respondents, which reduces the objectivity of the obtained data. Consequently, future research should provide additional data sources, such as interviews with managers and employees, to provide a deeper analysis of the research problem.

\section{References}

Antonakis, J., Avolio, B. J., \& Sivasubramaniam, N. (2003). Context and leadership: an examination of the nine-factor full - range leadership theory using the Multifactor Leadership Questionnaire. The Leadership Quarterly, 14, 261-295. https://doi.org/10.1016/S1048-9843(03)00030-4

Avolio, B. J., Bass, B. M., \& Jung, D. I. (1999). Reexamining the components of transformational and transactional leadership using the Multifactor Leadership Questionnaire. Journal of Occupational and Organizational Psychology, 72, 441-462. https://doi.org/10.1348/096317999166789

Babić, V., \& Savović, S. (2009). Značaj liderstva za uspeh procesa preuzimanja. Ekonomske teme, $1,47-61$.

Dung, L. T., \& Hai, P. V. (2020). The Effects of Transformational Leadership and Job Satisfaction on Commitment to Organisational Change: A Three-Component Model Extension Approach. The South East Asian Journal of Management, 14(1), 106-123. https://doi.org/10.21002/seam.v14i1.11585

Farahnak, L. R., Ehrhart, M. G., Torres, E. M., \& Aarons, G. A. (2020). The influence of transformational leadership and leader attitudes on subordinate attitudes and implementation success. Journal of Leadership \& Organisational Studies, 27(1), 98-111. https://doi.org/10.1177/1548051818824529

Haspeslagh, C., \& Jemison, B. (1987). Acquisitions: Myths and reality. Sloan Management Review, 28(2), 53-58.

Herold, D. M., Fedor, D. B., Caldwell, S., \& Liu, Y. (2008). The effects of transformational and change leadership on employees' commitment to a change: A multilevel study. Journal of Applied Psychology, 93(2), 346-357. https://doi.org/10.1037/0021-9010.93.2.346

Judge, T. A., \& Piccolo, R. (2004). Transformational and transactional leadership: A metaanalytic test of their relative validity. Journal of Applied Psychology, 89, 755-768. https://doi.org/10.1037/0021-9010.89.5.755

Kiessling, T., \& Harvey, M. (2006). The human resource management issues during an acquisition: The target firm's top management team and key managers. The International Journal of Human Resource Management, 17(7), 1307-1320. https://doi.org/10.1080/09585190600756798 
Long, C. S., Yusof, W. M. M., Kowang, T. O., \& Heng, L. H. (2014). The impact of transformational leadership style on job satisfaction. World Applied Sciences Journal, 29(1), 117-124. https://doi.org/10.5829/idosi.wasj.2014.29.01.1521

Nemanich, L. A., \& Keller, R. T. (2007). Transformational leadership in an acquisition: A field study of employees. The Leadership Quarterly, 18(1), 49-68. https://doi.org/10.1016/j.leaqua.2006.11.003

Nielsen, K., Yarker, J., Randall, R., \& Munir, F. (2009). The mediating effects of team and selfefficacy on the relationship between transformational leadership, and job satisfaction and psychological well-being in healthcare professionals: A cross-sectional questionnaire survey. International Journal of Nursing Studies, 46(9), 1236-1244. https://doi.org/10.1016/j.ijnurstu.2009.03.001

Parvin, M. M., \& NurulKabir, M. M. (2011). Factors affecting employee job satisfaction of pharmaceutical sector. Australian Journal of Business and Management Research, $1(9), 113-123$.

Pierce, J., \& Newstrom, J. (2000). Leaders \& the Leadership Process (2nd edition).Boston: McGrawHill.

Rafferty, A. E., \& Griffin, M. A. (2004). Dimensions of transformational leadership: Conceptual and empirical extensions. The Leadership Quarterly, 15(3), 329-354. https://doi.org/10.1016/j.leaqua.2004.02.009

Rafferty, A. E., \& Restubog, S. L. D. (2010). The impact of change process and context on change reactions and turnover during a merger. Journal of Management, 36(5), 1309-1338. https://doi.org/10.1177/0149206309341480

Savović, S. (2017). The impact of dimensions of transformational leadership on the postacquisition performance of an acquired company. Ekonomski Horizonti, 19(2), 95-108. https://doi.org/10.5937/ekonhor1702095S

Top, M., Akdere, M., \& Tarcan, M. (2015). Examining transformational leadership, job satisfaction, organisational commitment and organisational trust in Turkish hospitals: public servants versus private-sector employees. The International Journal of Human Resource Management, 26(9), 1259-1282. https://doi.org/10.1080/09585192.2014.939987

Wang, H. J., Demerouti, E., \& Le Blanc, P. (2017). Transformational leadership, adaptability, and job crafting: The moderating role of organizational identification. Journal of Vocational Behavior, 100, 185-195. https://doi.org/10.1016/j.jvb.2017.03.009

Yukl, G.A. (1999). An evaluation of conceptual weaknesses in transformational and charismatic leadership theories. The Leadership Quarterly, 10(2), 285-305. https://doi.org/10.1016/S1048-9843(99)00013-2

(C) 2021 by the authors. Submitted for possible open access publication under the terms and conditions of the Creative Commons (http://creativecommons.org/licenses/by/4.0/).

Attribution (CC BY) license 